\title{
The Development of Contextual Text Based Exposition Writing Teaching Materials of Class X Students in State 16 Senior High School, Medan
}

\author{
Refiansyah Habibie Rambe', M. Oky Fardian Gafari², Mutsyuhito Solin² \\ ${ }^{1}$ Master Student in State University of Medan, Indonesia \\ ${ }^{2}$ Students in State University of Medan, Indonesia \\ habibie1493@gmail.com
}

\begin{abstract}
This paper deals with The Development of Contextual Text Based Exposition Writing Teaching Materials of Class X Students in State 16 Senior High School, Medan. The method used in the development of teaching material research is the Borg and Gall models which used to develop a product. The product of the learning module that was developed was a contextual text-based exposition writing material for class $X$ students in state 16 Senior High School, Medan. This research and development refers to the theory of teaching material development proposed by Borg and Gall. The finding shows that Teaching Materials Development of Exposition Text Writing Based on Contextual is the development of teaching materials is needed by students and teachers in the learning process. This is due to improving the quality of learning to be better and more interesting. The use of contextual text-based teaching writing materials is considered more effective than the textbooks used by students. This is evidenced by better student learning outcome that is the use of textbooks (Pretest) 70.68\% with sufficient categories while the use of teaching materials for exposition text writing is based on contextual (Posttest) $81.40 \%$ with good categories. The effectiveness of teaching material based on the results of the pretest to posttest exposition text writing increased with a difference of $10.72 \%$. Based on this, the product developed has been good and tested in improving students' ability in writing exposition texts in class $X$ students in state 16 Senior High School, Medan.
\end{abstract}

Keywords : Teaching Materials Development, Exposition Text Writing, education, students

\section{Introduction}

Learning in the 2013 curriculum is now inseparable from the scientific learning model, which is a learning model designed so that students actively construct concepts, laws and principles through the 5M stages (observing, asking, collecting data, associating, and communicating (Safuiroh: 2016: 1Vol 5) However, it does not mean that it is only focused on one concept of the learning model, the teacher can choose any model based that is suitable to be applied in the class..

Safuiroh in his journal (2016: 7 Vol. 5), argues that there are 3 things that must be considered for teachers who want to choose the right learning model first, the suitability of learning models with attitude competencies in KI-1 and KI-2 and knowledge and skills competencies in accordance with KD-3 and / or KD-4); second, suitability of learning models with the characteristics of KD-1 (if any) and KD-2 which can develop competency attitudes and suitability of learning materials with demands KD-3 and KD-4 to develop knowledge and skills competencies; third, the use of a scientific approach that develops students' learning experiences through observing activities, questioning, experimenting / collecting information, associating, and communicating.

In line with that contextual based model and the application of exposition text writing material is a model and also material that can also be included in the above category $(5 \mathrm{M})$. According to Trianto (2016: 10), contextual learning is a concept of learning that helps 
teachers connect between the material they are teaching and the real world situation of students.

In addition, it also encourages students to make connections between their knowledge and their application in their daily lives by involving the seven main components of effective learning, there are: constructivism, questioning, inquiry, learning community, modeling, reflection, and authentic assessment.

So, the difference between the $5 \mathrm{M}$ model and the contextual model is the technical problem or the application in the class because each has its own style, this requires the teacher's creativity in making teaching materials that unite the model and learning material as interesting as possible.

The teacher is expected to play a role in determining the success of the learning process through a teaching material. This is also reinforced by the Academic Qualification Standards and Teacher Competence, that teacher as professional educators are expected to have the ability to develop teaching materials that are in accordance with existing mechanisms by taking into account the characteristics and environment of students.

Teaching materials are important in a process of learning activities, because the presence of teaching materials will certainly facilitate teachers in teaching and not only depend on conventional textbooks, but also make it easier for students to get knowledge well and efficiently.

This is in line with the opinion of Prastowo (2015: 301), who argues that the benefits obtained by the teacher with teaching materials are not dependent solely on textbooks, while the benefits obtained by students are, the creation of interesting learning, motivational growth, reducing dependence and get convenience in studying each indicator contained in the learning device prepared by the teacher.

Based on preliminary observations in high school to be studied, it can be seen that the teacher only uses compulsory books from the Ministry of Education and Culture, namely Indonesian language books SMA / MA / SMK / MAK class X curriculum 2013 which know that in writing exposition texts there are limitations to the themes specified in in the book that is only limited to economic and political themes, this is a difficult for students because not all understand about economics and politics, so the impression of the theme being raised is too high for high school students.

\section{Review of Literature}

\subsection{Teaching Materials}

Teaching materials are materials or subject matter that are systematically arranged, which are used by teachers and students in the learning process (Pannen in Prastowo 2015: 17). Then Majid (2013: 173) suggested teaching materials were all forms of material used to help teachers / instructors in carrying out teaching and learning activities. Furthermore Widodo and Jasmadi (2012: 40) state teaching materials are a set of learning tools that contain learning material, methods, boundaries, and ways of evaluating which are arranged systematically and attractively with the aim of achieving competence or sub-competence in all its complexity. Teaching materials can take the form of books, texts, modules, handouts, worksheets, and other forms.

Dick, Carey (2013: 230), argues that "instructional material contain the content either written, mediated, or facilitated by an instructor that a student as use to achieve the objective also include information that the learners will use to guide the progress". So it can be seen 
based on the opinion above, Dick, Carey explained that the teaching material contained content that was written, mediated, or facilitated by the instructor used by students to achieve these goals and which included information about students that could be used to direct them to improvement.

Then another opinion can be found from Djumingin (2017: 53), which states "teaching materials are the resources a teacher uses to deliver instruction. Each teacher requires a range of tools to draw upon in order to assist and support student learning". It can be interpreted that teaching materials are sources used by teachers in delivering lessons.

The same thing can also be seen from the opinion of Prastowo (2015: 17), who concluded that teaching materials are all materials (both information, tools and text) which are arranged systematically, which displays a complete figure of competence that will be mastered by students and used in the process learning with the aim of planning and reviewing the implementation of learning, for example textbooks, modules, handouts, worksheets, model mockups, audio teaching materials, integrative teaching materials, and so on.

\subsection{Learning Module}

According to Majid (2013: 176) the module is a book written with the aim that students can learn independently without or with the guidance of the teacher. Modules can be viewed as teaching program packages. Therefore a module is teaching materials created by teachers to help students in learning, both independently and mentally.

Next is Smaldino, Lowthet, and Russel (2016: 118) stating "A module is an instructional package dealing with single conceptual unit of subject matter. It is attempt to individual learning by enabling the student to master one unit of contents before moving to another" which it can be interpreted that the module is an instructional package that deals with a single conceptual unit of a subject matter.

So, a module is a learning tool that is deliberately created as a learning tool for students for certain subject matter according to their needs. Hamdani (2011: 219) defines that the module is a tool or means of learning that contains material, methods, boundaries of learning materials, instructions for learning activities, exercises and how to evaluate which are designed systematically and attractively to achieve the expected competencies and can be used independent.

Furthermore Sabri (2017: 143), states that the module is a complete unit consisting of a series of learning activities arranged to assist students in achieving the goals that have been formulated. Then Surahman in Prastowo (2015: 105), states that the module is the smallest unit of learning that can be studied by individual students (selfinstructional), after participants complete one unit in the module, then students can move forward and learn the next unit of module.

Based on some opinions above, it can be concluded that the module is a set of printshaped teaching materials which contain one subject matter that is discussed in depth complete with displaying discussion materials accompanied by practice questions and answer keys to provide assistance to students who do not know or wrong in answering.

\subsection{Exposition Text}

Priyatni (2014: 91) exposition text is a text used to convince readers of opinions expressed in a number of supporting arguments. Furthermore Kosasih (2014: 25) states that the exposition text is a text that presents an opinion or idea that is viewed from the author's 
perspective and serves to convince the other party that the arguments presented are correct and based on facts.

Then Keraf (2011: 3) argues that exposition text is one form of writing or rhetoric that seeks to explain and describe a point of thought, which can broaden the views or knowledge of someone who reads the description. Rahayu (2007: 160) states the exposition text is a form of writing that attempts to explain and describe a subject that can broaden the views and knowledge of the reader in revealing the facts.

Another opinion Saddhono and Slamet (2014: 160) states that exposition text is a variety of discourses intended to explain or describe things that can expand or increase the knowledge and views of the reader.

Based on the opinions above, it can be concluded that the exposition text is writing that aims to provide an explanation of a subject with various ideas, opinions, and supported by data in order to provide knowledge / information to the reader that what is conveyed is correct based on the author's perspective.

\subsection{Contextual Based Learning Method}

According to Trianto $(2016: 10)$ contextual learning is a concept of learning that helps teachers connect between the material they are teaching and the real world situation of students. Besides that, it also encourages students to make connections between their knowledge and their application in their daily lives by involving the seven main components of effective learning, there are: constructivism, questioning, inquiry, learning community, modeling, reflection and authentic assessment.

Then Nurhadi (2010: 4) explains that contextual learning is a unique concept of learning because the teacher presents real-world situations into the classroom and encourages students to make connections between the knowledge they have and the application in their lives as family members and society.

Then Majid (2014: 228), explains that contextual learning is a learning concept that helps teachers associate material taught with students' real world situations and encourages students to make connections between their knowledge and their application in their lives as family members and society.

Moh. Rudiyanto in his journal "The Implementation of Contextual Teaching and Learning (CTL) in English Class" volume 2 (2009:232) explains that The CTL system is an educational process that aims to help student's see meaning in the academic material they are studying by connecting academic subjects with the context of their daily lives, that is, with the context of their personal, social, and cultural circumstance.

\section{Research Method}

The location of this research was conducted in class X of state 16 Senior High School, Medan. The reason for choosing this location is because there has never been a research on the same problem, the location of the school which is relatively easy to reach. When the study was held January 7-22, 2019

The population in this research and development is all students of class X state 16 Senior High School, Medan. To determine the effectiveness of the module developed, it only takes random sampling techniques, and then the sample set in the study is class X MIA 4, which amounts to 32 students. 
The method used in the development of teaching material research uses the Borg and Gall models used to develop a product. The product of the learning module that was developed was a contextual text-based exposition writing material for class $\mathrm{X}$ students of state 16 Senior High School, Medan. This research and development refers to the theory of teaching material development proposed by Borg and Gall. Sugiono (2015: 409).

\section{Discussion}

This paper is a research and development which aims to produce a product in the form of contextual text exposition modules. Borg \& Gall in Sugiono (2015: 412) explains that "Research and Development" in education is an industry-based development model where the findings of research are used to designing learning products, which are then systematically tested in the field, evaluated and refined to produce a learning product that meets certain standards, that are: effective, efficient and quality. Effective is a measure of the superiority of the product in achieving the learning objectives or competencies in accordance with the criteria or indicators of learning completeness standards that have been previously set by the school, institution, or government. Efficient is the product developed to be able to provide assurance that in terms of time, cost and energy needed to achieve certain learning objectives or competencies are shorter, cheaper, and lighter when compared to using previous learning products. Quality is the product developed must meet industry standards from various aspects.

The products are shown to produce better quality learning. Of the many existing research and development models, which specifically direct research and development in the field of education is the R \& D model developed by Borg and Gall. Steps for implementing the model include preliminary studies, initial product development (planning), product validation and product testing (individual, small group, limited service trials).

The first stage of the preliminary study is the earliest stage in the product development process. Needs analysis is an activity carried out in a preliminary study. This is corroborated by the opinion of Sanjaya (2008: 91) which states that the importance of needs analysis is in accordance with the design goals developed to help resolve learning needs for students.

The analysis of teaching material needs is carried out to identify the teaching materials that have been used and the instructional materials desired in the learning process. The results of the analysis of teaching material requirements were obtained using a questionnaire. From the results of the questionnaire it was found the fact that all this time teachers and students only used textbooks from the Ministry of Education and Culture in the learning process in schools without any other companion teaching materials. In addition, teachers and students also need teaching materials that are appropriate to their environmental context, especially during exposition text learning. So far, the text presented in writing exposition texts that have been used in schools using themes that I think are "too heavy" for class X high school students who are only limited to the political and economic fields, therefore the development of teaching materials that are appropriate to the context of the student environment is needed so that learning exposition text writing can be more directed and easy to understand students also efficient for the teacher in teaching it.

The second stage is the initial product development. At this stage, an outline of the material consists of $4 \mathrm{KDs}$ which will be described in the module. Then the module structure design that clearly shows the module starts from the module cover, concept map, usage instructions, learning activities, student worksheets, summaries and bibliography. 
After developing and producing a product in the form of a learning module, a material expert and design expert validated it. At the time of validation there are several improvements or revisions to improve product quality. There are some suggestions from the expert validators of the material and design:

Table 4.1 Suggestion from material experts

\begin{tabular}{|l|l|}
\hline No. & \multicolumn{1}{|c|}{ Suggestions } \\
\hline 1 & Contextual-based exposition text can be limited to the background of North Sumatra. \\
\hline 2 & Improve the use of words to be more communicative. \\
\hline 3 & The high-reasoning matter needs to be sharpened again in the stimulus. \\
\hline 4 & Note the use of spelling must match PUEBI. \\
\hline 5 & Clarify the source of the reading in each exposition text quoted. \\
\hline
\end{tabular}

Table 4.2 Suggestion from the expert validators of the material

\begin{tabular}{|l|l|}
\hline No. & \multicolumn{1}{|c|}{ Suggestions } \\
\hline 1 & Revised the appearance of colors on the cover to make it more attractive. \\
\hline 2 & Revision of training views for students. \\
\hline 3 & Show illustrations that can illustrate the story presented in the example exposition text. \\
\hline 4 & Don't use too many colors in the module. \\
\hline 5 & The size of the title of the teaching material is enlarged. \\
\hline 6 & Fix the location of the logo on the cover. \\
\hline
\end{tabular}

Each assessment result will be classified with the percentage criteria table for the appearance of indicators in the teaching materials as follows:

Table 4.3 Result classified with the percentage

\begin{tabular}{|l|l|}
\hline Answer & Score \\
\hline Very Good & $90-100 \%$ \\
\hline Good & $80-89 \%$ \\
\hline Enough & $60-79 \%$ \\
\hline Poor & $40-59 \%$ \\
\hline Very Poor & $<40 \%$ \\
\hline
\end{tabular}

(Arikunto, 2015:46)

The results of the content worthiness assessment obtained an average percentage of $91.48 \%$ with the criteria of "very good". The results of the worthiness aspect of presentation obtained an average percentage of $94 \%$ with the criteria of "very good" and the results of language assessments obtained an average percentage of $93.75 \%$ with the criteria of "very good".

After that, the next is an assessment of the design of the product produced. This assessment was carried out by design experts intended to improve the display quality of contextual text based exposition writing materials. The results of the validation of teaching materials by design experts obtain an average percentage of $90 \%$ with the criteria "very good".

The third step is to test the product. Product trials are divided into 3 parts, namely: individual trials, small group trials and limited field trials. Individual trials obtained a percentage of $85.04 \%$ with the criteria of "good". The results of the assessment of material indicators are in the "good" category with an average percentage of $81.25 \%$. Language 
indicators obtain an average percentage of $88.88 \%$ with the criteria of "good" and indicators of attraction obtain an average percentage of $85 \%$ with a good category ". Some of the data above show that contextual text-based exposition writing teaching materials are in accordance with the needs of students.

The shortcomings in this individual trial are those that are in the criteria of "enough" or with a percentage of $75 \%$. Of the 12 item rating points there are 4 items with a percentage of $75 \%$. This is a matter that needs to be corrected again to be increased in small group trials. Following are the indicators, namely about the module assessment presented easily understood, presentation of material encourages discussion, makes student learning more directed and coherent, makes students not bored with modules. This is of course not satisfactory because there are still those who are in the "enough" criteria. Because good teaching materials are like the opinion of Djumingin (2017: 53) Teaching materials are the resources a teacher uses to deliver instruction. Each teacher requires a range of tools to draw upon in order to assist and support student learning. It is a resource that teachers can use to convey various instructions (communicative in nature). The teacher makes a series of tools that can be used to support student learning.

The results of the assessment of small group trials were conducted to re-examine student responses to the module as well as weaknesses after individual trials were conducted. Small group trials got a percentage of $86.26 \%$ with the criteria of "good", material indicators obtained an average percentage of $84.72 \%$ with the criteria of "good", language indicators obtained an average percentage of $87.96 \%$ with the criteria of "good" and indicators of attraction get an average percentage of $84.72 \%$ with the criteria of "very good". After a small group trial has been completed, the next stage of the trial is limited.

Overall, the trial of this small group is already in the criteria of "good". There are 12 item rating points, the average overall score shows a percentage of $86.26 \%$, of course there is a slight increase from the previous trial. The lowest value of $80.5 \%$ contains the sentence that has not been used effectively on the module is one drawback and will be increased in the next trial. The highest value is $94.4 \%$ which contains an interesting display module. There is a range that is quite far between the lowest and highest values, which is approximately $13.9 \%$. So based on these findings a series of improvements were made to be used in the next trial. The advantages of this module are located in the content content around the discussion in Medan city. This is something that makes students interested because they feel familiar with things that exist in their environment. In line with the opinion of Anwar (2010: 93), which states that a good module must be user friendly, the module should meet familiar rules and be friendly / familiar with the user.

Limited field trials were conducted to determine the extent of the contextual use of exposition text-based teaching materials for students. Limited field trials obtained an average percentage of $94.85 \%$ with the criteria of "very good". The results of the assessment on the material indicator obtained an average percentage of $94.92 \%$ with the criteria of "very good", the language indicator obtained an average percentage of $94.01 \%$ with the criteria of "very good" and the last indicator of attraction gained an average percentage of $95.63 \%$ with the criteria of "very good". Thus the teaching material of the exposition text based on the conceptual approach has met the needs of learning.

Overall, this limited field trial is already in the criteria of "very good". There are 12 item rating points, the average overall score shows a percentage of $94.85 \%$, of course far adrift with the previous trial which amounted to $86.26 \%$ which has a difference of $8.59 \%$. This is based on the evaluation results from previous trials and perfect things that are still lacking. 
With this high value acquisition, of course students feel satisfied with the teaching materials produced because they have met their expectations of a contextual based learning module. The lowest value is $92.2 \%$, but this is already in the "good" category, containing the module material, making students happy to learn it. The highest score of $97.7 \%$ contains an attractive module display, the previous difference is quite far between the highest and lowest values in the trial this time thinning at 5.5\%. This is an improvement in learning and evaluation material for the improvement of the module in the future so that the goal of making the module is successful, as Prastowo believes (2015: 108), so that students can learn independently without or with the guidance of teachers / educators.

The worthiness of contextual text-based exposition text teaching material is obtained from the results of validation carried out by material experts and design experts. Learning material developed through a contextual approach has its own characteristics. MONE (2012: 5) the characteristics referred to relating to the characteristics of the contextual approach include: 1) the relationship with the context of the environment in which students live which includes the physical environment, social environment, cultural environment, political environment, and psychological environment; 2) material in the form of facts, concepts, principles, procedures, values, and attitudes of KI, KD, and indicators; 3) linkages with other integrated subject matter; 4) able to be applied in real life students; 5) provide direct experience through inquiry activities; 6) developing cooperative abilities as well as independence; and 7) developing the ability to reflect.

The worthiness of teaching materials in terms of material includes aspects of assessment, namely the worthiness of content, the worthiness of presenting and the worthiness of language. The aspect of content worthiness obtained an average percentage of $91.48 \%$ with the criteria of "very good". The worthiness aspect of the content includes four subcomponents, namely (1) the suitability of the material with KI and KD, (2) the accuracy of the material, (3) the updating of the material and (4) encouraging curiosity. The first subcomponent obtained an average percentage of $95.83 \%$ with the criteria of "very good". In the second sub-component obtained an average percentage of $85.71 \%$ with the criteria of "very good". In the third sub-component obtained an average percentage of $96.87 \%$ with the criteria of "very good". The last sub-component obtained an average percentage of $87.50 \%$ with the criteria of "good".

The shortcomings of teaching materials produced can be seen from the assessment of material experts. In the aspect of worthiness the content lack of teaching materials lies in the accuracy aspect of the terms because it can get a percentage of $75 \%$ including the criteria "enough". The rest are in the criteria of "good" and "very good" this can be seen from 16 items of assessment 1 in the category of "enough" with a percentage of $75 \%$, namely in the accuracy of terms that are still lacking in delivery, 10 items get a percentage of $87,5 \%$, namely the completeness of the material, the completeness of the concept, the accuracy of the facts, the accuracy of the image, the accuracy of the notation, the accuracy of the reference, the suitability of the material with the development of science, encouraging curiosity, the ability to ask questions, and 5 items with a percentage of $100 \%$ at the breadth of material aspects, the depth of the material, using case examples in everyday life, images, diagrams, and illustrations according to daily life, librarianship updates. The lowest distance of $75 \%$ to the highest $100 \%$ has a difference of $25 \%$.

The worthiness aspect of presentation obtained an average percentage of $85.70 \%$ with the criteria of "good". The feasibility aspect of presentation includes three sub-components, namely 1) presentation techniques, 2) learning presentation and 3) presentation. The results of 
the assessment in the first sub-component obtained an average percentage of $87.50 \%$ with the criteria of "good". In the second sub-component, the average percentage was $98.43 \%$ with the criteria of "very good". Finally in the third sub-component obtained an average percentage of $98.43 \%$ with the criteria of "very good".

Overall, the assessment of the feasibility of this presentation has been classified as the criteria of "good" and "very good". It can be seen from a total of 13 items of assessment. There are 4 items with a percentage of $87.5 \%$ : systematic consistency of presentation in learning, conceptual wrangling, centered to students, examples of questions in each learning activity. More than 9 items with a percentage of $100 \%$, that is involvement of students, stimulating students' abilities, practice questions at the end of each lesson, key answers to practice questions, introduction, table of contents, glossary summary , Bibliography. The lowest value is $87.7 \%$ and the highest is $100 \%$ with a difference of $12.5 \%$.

The worthiness aspect of language gets an average percentage of $93.75 \%$ with the criteria of "very good". The worthiness aspect includes six sub-components, namely 1) straightforward, 2) communicative, 3) dialogical and interactive, 4) conformity with the level of development of students, 5) the fidelity and integration of the flow of thought and 6) the use of terms, symbols and icons. The first sub-component obtained an average percentage of $100 \%$ with the criteria of "very good". The second sub-component obtained an average percentage of $93.75 \%$ with the criteria of "very good". The third sub-component obtained an average percentage of $87.50 \%$ with the criteria of "very good". The fourth sub-component obtained an average percentage of $93.75 \%$ with the criteria of "very good". The fifth subcomponent obtained an average percentage of $87.50 \%$ with the criteria of "good". The last sub-component obtained an average percentage of $100 \%$ with the criteria of "very good".

In this language worthiness aspect of 13 items of assessment points there is 1 that has a percentage of $75 \%$ with the category "enough" containing the ability to encourage critical thinking, there are 4 items that have a percentage of $87.5 \%$ namely the accuracy of language use, compatibility with the emotional level of students, intertwining between paragraphs, interdependence between learning activities, the remaining 8 items have a percentage of $100 \%$ namely the accuracy of sentence structure, effectiveness of sentences, conformity of terms, readability of messages, ability to motivate messages, suitability of intellectual development of students, consistency of use of terms, consistency of use of symbols. The lowest distance to the highest value is $25 \%$.

Based on these data, it can be concluded that the content of the contextual-based exposition text writing module is in accordance with the cognitive level and ability of students. Therefore this module is feasible to be tested in class X students of SMA 16 Medan.

Then in the aspect of worthiness of graphics (design) obtain an average percentage of $90 \%$ with the criteria of "very good". The aspect of graphic feasibility reads three subcomponents, namely 1) module size, 2) module cover design and 3) module content design. The first sub-component obtained an average percentage of $93.75 \%$ with the criteria of "very good". The second sub-component obtained an average percentage of $91.66 \%$ with the criteria of "very good". The third sub-component obtained an average percentage of $84.21 \%$ with the criteria of "good".

The shortcomings are seen from the whole of the 30 items rated the lowest value there are 9 items in the criteria of "enough" with a percentage of $75 \%$, then there are 11 items of assessment are in the criteria of "good" with a percentage of $87.5 \%$, and finally there are 9 items assessment with the criteria of "very good" with a percentage of $100 \%$. Teaching materials for writing contextual exposition-based texts have been revised and improved in 
accordance with the suggestions and input from the design experts described earlier. Thus it can be concluded that this teaching material is feasible to be tested to high school students and is suitable for use in Indonesian language learning especially in exposition text material.

\section{Conclusion}

Based on the results of the needs analysis states that the development of teaching materials is needed by students and teachers in the learning process. This is due to improving the quality of learning to be better and more interesting. The use of contextual text-based teaching writing materials is considered more effective than the textbooks used by students. This is evidenced by better student a learning outcome that is the use of textbooks (Pretest) $70.68 \%$ with sufficient categories while the use of teaching materials for exposition text writing is based on contextual (Posttest) $81.40 \%$ with good categories. The effectiveness of teaching material based on the results of the pretest to posttest exposition text writing increased with a difference of $10.72 \%$. Based on this, the product developed has been good and tested in improving students' ability in writing exposition texts in Class X Medan 16 High School.

\section{References}

Abbas, Saleh. 2016. Pembelajaran Bahasa Indonesia Yang Efektif di Sekolah Dasar. Jakarta: Dikti

Ahmadi, et al. 2011. Strategi Pembelajaran Sekolah Terpadu. Jakarta: Prestasi Pustaka

Arikunto, S. 2015. Dasar-Dasar Evaluasi Pendidikan. Jakarta: Bumi Aksara

Dalman. 2014. Keterampilan Menulis. Jakarta: PT Rajagrafindo Persada.

Dick and Carey. 2013. The Syematic Design of Instuction. New York: Harper Collins Publisher

Djumingin, Sulastriningsih. 2017. Strategi dan Aplikasi Model Pembelajaran Inovatif. Jakarta: Bumi Aksara

Depdiknas. 2006. Kurikulum Standar Isi 2006. Jakarta: Badan Standar Nasional Pendidikan

Depdiknas. 2012. Teknik Belajar Dengan Modul. Jakarta: Dirjen Pendidikan Dasar dan Menengah

Ilham Anwar. 2010. Pengembangan Bahan Ajar Bahan Kuliah Online. Bandung: Direktori UPI

Keraf, Gorys. 2011. Eksposisi dan Deskripsi.Flores. Nusa Indah

Kosasih, E. 2014. Jenis-Jenis Teks; Analisis Fungsi, Struktur, dan Kaidah, serta Langkahlangkah Penulisannya. Bandung. Yrama Widya

Majid, Abdul. 2013. Perencanaan Pembelajaran: Mengembangkan Standar Kompetensi Guru. Bandung: PT Remaja Rosda Karya

Moh. Rudiyanto, "The Implementation of Contextual Teaching and Learning (CTL) in English Class” Jurnal OKARA, Volume II, Nomor 4 (Nopember, 2009), 232.

Kokom, Komalasari. 2014. Pembelajaran Kontekstual Konsep dan Aplikasi . Bandung. PT Rafika Aditama

Kurnia. 2015. Penerapan Model Problem Based Learning untuk Meningkatkan Kemampuan Menulis Teks Eksposisi. e-journal Program Pascasarjana UNASMAN (Volume 9). 
Nasution, Syarifuddin. 2017. Pengaruh Model Pembelajaran Kontekstual Dan Pemahaman Kalimat Efektif Terhadap Kemampuan Menulis Teks Eksplanasi Siswa SMP Negeri 1 Dolok Masihul. Medan. Universitas Negeri Medan

Nuraini, dkk. 2015. Implementasi Kurikulum 2013 Pada Pembelajaran Menulis Teks Eksposisi (Studi Kasus Di Kelas X Smk Negeri 1 Karanganyar) Volume 3 Nomor 3). Jakarta. Universitas Sebelas Maret.

Prastowo, Andy. 2015. Panduan Kreatif Membuat Bahan AjarInovatif. $\quad$ Yogyakarta: Diva Press

Tarigan. 2014. Menulis Sebagai Suatu Keterampilan Berbahasa. Bandung. Alfabeta

Trianto, 2016 Mendesain Model Pembelajaran Inovatif-Progresif. Jakarta: Kencana

Safuiroh, Gunawan. 2016. Pengembangan Modul Pembelajaran Bahasa Indonesia Berbasis Life Skills untuk kelas X SMAN 7 Surakarta. (Nomor 1 Volume5). Jakarta Universitasn Sebelas Maret

Sriyono. 2013. Teknik Belajar Mengajar dalam CBSA: Jakarta. Rineka Cipta

Sugiono, Anas. 2015. Metode Penelitian Kualitatif, Kuantitatif \& RND. Bandung: Alfabeta

Priyatni, E.T. 2014. Desai Pembelajaran Bahasa IndonesiaDalam Kurikulum 2013. Jakarta : Bumi Aksara

Rahayu, Minto. 2007. Bahasa Indonesia di Perguruan Tinggi; MataKuliah Pengembangan Kepribadian. Jakarta : Grasindo

Sabri, Ahmad. 2017.Strategi Belajar Mengajar.Ciputat. Quantum Teaching

Semi, M. Atar. 2017.Menulis Efektif. Padang: Angkasa Raya

Samsudin, Asep. Jurnal Penelitian Pendidikan. Peningkatan Kemampuan Menulis Eksposisi Berita dan Menulis Eksposisi Ilustrasi Siswa Kelas X Melalui Model Pembelajaran Kooperatif Terpadu Membaca dan Menulis. Vol 13 No.2 October 2012

Saddono, Kundharu, dan Slamet. 2014. Pembelajaran Keterampilan Berbahasa Indonesia Teori dan Aplikasi. Yogyakarta: Graha Ilmu

Smaldino, Lowther, dan Russel. 2016. Developing Module on Constructivist Learning Strategis to Promote Students's Independence and Performance. International Journal of Education, 7 (1): 18-28

Sugiyono, 2015. Metode Penelitian Pendidikan Pendekatan Kualitatif, Kuantitatif, dan $R \&$ D. Bandung. Alfabeta .

Widodo, Chomsin S. dan Jasmadi. 2013. Panduan Menyusun Bahan Ajar Berbasis Kompetensi. Jakarta: PT Elex Media Komputindo. 